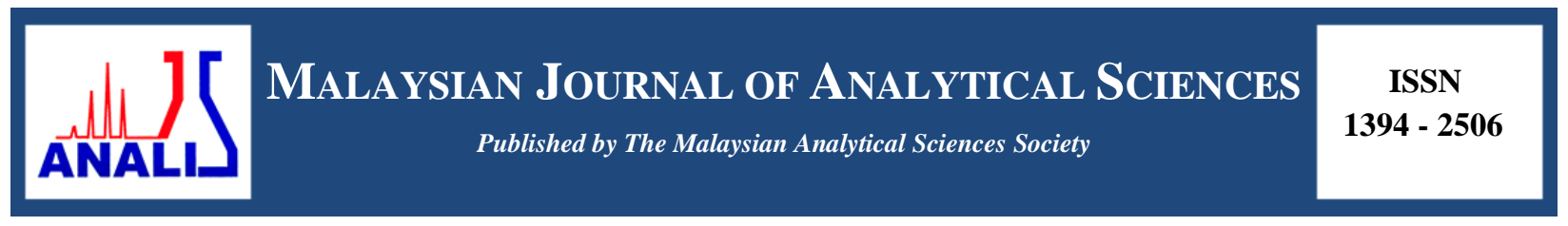

\title{
THE EFFECTS OF ZEOLITE ON MECHANICAL AND MORPHOLOGICAL PROPERTIES OF NR/ENR MEMBRANES
}

\author{
(Kesan Zeolit pada Sifat Mekanikal dan Morfologi Membran NR/ENR) \\ Kritsada Phatcharasit ${ }^{1} *$ and Wirach Taweepreda ${ }^{2}$ \\ ${ }^{1}$ Department of Rubber and Polymer Engineering, \\ Faculty of Engineering, Thaksin University, 93110 Phatthalung, Thailand \\ ${ }^{2}$ Department of Materials Science and Technology, \\ Faculty of Science, Prince of Songkla University, 90110 Songkla, Thailand \\ *Corresponding author: krit_off@hotmail.com
}

Received: 16 April 2017; Accepted: 7 March 2018

\begin{abstract}
The main focus of this research is on the organic-inorganic membranes. In this study, the effects of zeolite on natural rubber (NR)/epoxidized natural rubber (ENR) membranes properties were investigated. NR/ENR blends were combined with zeolite in various contents at $0-50 \mathrm{phr}$ by the two-roll mill. The rubber compounds were produced by compression molding at $150{ }^{\circ} \mathrm{C}$ to form membranes with thickness of not more than $0.4 \mathrm{~mm}$. NR/ENR blends with zeolite were characterized according to cure characteristics, mechanical properties, swelling properties and scanning electron microscope (SEM). It was found that the mechanical properties of the blends increased with the addition of zeolite for $10 \mathrm{phr}$ while the cure time $\left(\mathrm{t}_{\mathrm{c} 90}\right)$ increased with increasing zeolite content. Membranes swelling increased with increasing amount of zeolite (zeolite at 30 phr produced the best results). Meanwhile, the micrograph showed a surface filled with pores-like small holes with the addition of zeolite in the NR/ENR membranes.
\end{abstract}

Keywords: natural rubber, epoxidized natural rubber, zeolite, membrane

\begin{abstract}
Abstrak
Membran organik-bukan organik hibrid merupakan fokus utama dalam kajian ini. Kesan zeolit ke atas sifat-sifat getah asli (NR)/getah asli terepoksida(ENR) telah dikaji di dalam eksperimen ini. Campuran NR/ENR dengan zeolit dalam pelbagai kandungan pada 0-50 phr telah dijalankan oleh pengisar dua gulung. Sebatian getah asli tersebut telah dihasilkan melalui pengacuan mampatan pada $150{ }^{\circ} \mathrm{C}$ untuk membentuk membran pada ketebalan tidak melebihi $0.4 \mathrm{~mm}$. Campuran NR/ENR dan zeolit ini telah dikaji berdasarkan beberapa aspek iaitu sifat-sifat perawatan, mekanikal, pembengkakan dan pengimbasan mikroskop elektron (SEM). Kajian ini mendapati bahawa sifat mekanikal campuran ini meningkat dengan pertambahan zeolit pada 10 phr manakala masa rawatan $\left(\mathrm{t}_{\mathrm{c} 90}\right)$ juga meningkat dengan peningkatan kandungan zeolit. Pembengkakan membran juga meningkat dengan peningkatan jumlah zeolit (zeolit pada $30 \mathrm{phr}$ adalah yang terbaik). Mikrograf menunjukkan permukaan yang dipenuhi dengan lubang kecil seperti liang dengan pertambahan zeolit dalam NR/ENR membran.
\end{abstract}

Kata kunci: getah asli, getah asli terepoksida, zeolit, membran 


\section{Phatcharasit \& Taweepreda: THE EFFECTS OF ZEOLITE ON MECHANICAL AND MORPHOLOGICAL PROPERTIES OF NR/ENR MEMBRANES}

\section{Introduction}

Membrane technologies have developed as a workable and cost effective treatment alternative to wastewater, treat water, and air pollution. Membrane process is favored over conventional techniques because process less, consumes low energy and very effective and selective [1]. In addition, membrane can also be made from organic (natural rubber and polymer) and inorganic (ceramic, carbon, silica, zeolite and other) can be classified into 2 main groups based on its structure: porous and dense (non-porous) inorganic membranes. Nowadays, hybrid organic-inorganic membranes have been growing rapidly. Compared to certain inorganic membranes, polymeric membranes have relatively low separation performance. However, the processing flexibility and low cost of polymers still makes them highly attractive for many applications [2].

Natural rubber (NR) has been applied for a long time in several industrial and medicinal segments. More recently, NR compounds and membranes have attracted attention due to their great potential for biological and technological applications [3]. The NR can employ to produce transdermal drug delivery systems where it is the controlling layer membrane. Epoxidized natural rubber (ENR) is a unique elastomeric polymer derived from the chemical modification of natural rubber with epoxidized group randomly with $25 \%$ and $50 \%$ (ENR-25 and ENR-50). ENR is miscible with more polar rubber, good oil resistance, highly damping and low gas permeability [4]. Zeolites are very potential membrane materials because of their resulting pore sizes with zeolite mixed into natural rubber, effect to mechanical properties and vulcanizates of natural rubber [5].

In this study, the NR/ENR/Zeolite membrane was prepared by two-roll mill and the influence of zeolite as filler on the cure characteristics of the vulcanizates, mechanical properties, swelling properties and scanning electron microscope (SEM) and compared.

\section{Materials}

\section{Materials and Methods}

The natural rubber used in this study was STR 5L and ENR-50 were manufactured by Union Rubber Product Corporation Co., Ltd. and Muang Mai Guthrie Public Co., Ltd. Thailand., respectively. Zinc oxide (ZnO), stearic acid, wingstay L, sulphur and 2-mercaptobenzothiazole (MBT) were obtained from Kij Paiboon Chemical Ltd., Thailand. Zeolite type Sodium alumosilicate has a structural formula $\left(\mathrm{Na}_{12}\left[\mathrm{Al}_{12} \mathrm{Si}_{12} \mathrm{O}_{48}\right] \cdot 27 \mathrm{H}_{2} \mathrm{O}\right)$ was purchased from Sigma-Aldrich Co., Ltd.

\section{Preparation of membranes}

The membrane compound composition used in the present study is given in Table 1. The compound was prepared by mixing NR/ENR blends loaded with zeolite as filler using two-roll mill for 13 minutes and then the mixes were kept at room temperature for 24 hours before testing. Thereafter, the membrane compound was compressed and vulcanized at $150{ }^{\circ} \mathrm{C}$ to formed sheet with thickness approximately not over than $0.4 \mathrm{~mm}$. The cure time determined using a moving die rheometer (Alpha, MDR-2000).

\section{Characterization of membranes}

The mechanical properties of membranes were carried out using a LLOYD instrument tensile tester. The test was done according to ASTM D412. Across head speed of $500 \mathrm{~mm} / \mathrm{min}$ with load cell of $100 \mathrm{~N}$. The swelling test was carried out according to ISO 1817. The cured specimens, with dimensions of $30 \mathrm{~mm} \times 5 \mathrm{~mm} \times 2 \mathrm{~mm}$, followed by immersion in a deionized water for 72 hours at room temperature $\left(25^{\circ} \mathrm{C}\right)$ and the phase morphology of the membranes was studied using scanning electron microscopy (SEM, JEOL JSM-5800 LV). 
Table 1. The compounds composition of NR/ENR blends with zeolite

\begin{tabular}{lccccc}
\hline \multirow{2}{*}{ Ingredients } & \multicolumn{6}{c}{ phr (part per hundred of rubber) } \\
\cline { 2 - 6 } & $\mathbf{1}$ & $\mathbf{2}$ & $\mathbf{3}$ & $\mathbf{4}$ & $\mathbf{5}$ \\
\hline STR 5L & 50 & 50 & 50 & 50 & 50 \\
ENR-50 & 50 & 50 & 50 & 50 & 50 \\
ZnO & 2.5 & 2.5 & 2.5 & 2.5 & 2.5 \\
Stearic acid & 1 & 1 & 1 & 1 & 1 \\
MBT & 1.5 & 1.5 & 1.5 & 1.5 & 1.5 \\
Wingstay L & 1 & 1 & 1 & 1 & 1 \\
Sulphur & 2 & 2 & 2 & 2 & 2 \\
Zeolite & \multicolumn{7}{c}{ vary $(0,5,10,20,30$ and 50) } \\
\hline
\end{tabular}

\section{Cure characteristics}

\section{Results and Discussion}

The scorch time $\left(t_{s 2}\right)$, Optimum cure time $\left(t_{c 90}\right)$, Minimum torque $\left(M_{L}\right)$, Maximum torque $\left(M_{H}\right)$ and the torque difference between the Minimum and Maximum torque $(\Delta M)$ of NR/ENR/Zeolite compounds are summarized in Table 2 and Figure 1. It was found that $\Delta M$ is related to the crosslink density of the compound, the value of $M_{H}$ and the torque difference of the compound increased with increasing zeolite loading.

The measured torque is proportional to the system elasticity, viscosity and the crosslinking process is expected to increase the torque along with the period of vulcanization. Torque value of the rubber compound is increased due to the rigidity of the filler. That is, when the amount of fill increases, the rigidity increases, resulting in higher torque value. In other words, when increasing the amount of zeolite, the viscosity increases [11-13]. The cause of viscosity increase may be due to interactions between zeolites $[12,13]$. The $t_{s 2}$ decreased with increasing zeolite composition due to the interaction between the zeolite surfaces. The $t_{c 90}$ increased with increasing zeolite composition due to the acidity effect of zeolite [7]. Because the filler-filler interactions occurred because silica has a number of hydroxyl groups on its surface and there was accelerated adsorption on the silica surface [6].

Table 2. Cure characteristics of the NR/ENR/Zeolite compounds

\begin{tabular}{lccccc}
\hline NR/ENR/Zeolite & $\begin{array}{c}\text { Minimum Torque } \\
\boldsymbol{M}_{\boldsymbol{L}}(\mathbf{d N} \mathbf{~ m})\end{array}$ & $\begin{array}{c}\text { Maximum Torque } \\
\boldsymbol{M}_{\boldsymbol{H}}(\mathbf{d N} \mathbf{~ m})\end{array}$ & $\begin{array}{c}\boldsymbol{\Delta M} \\
\mathbf{( d N} \mathbf{m})\end{array}$ & $\begin{array}{c}\text { Scorch } \\
\text { Time } \\
\boldsymbol{t}_{\mathbf{2} 2}(\mathbf{m i n})\end{array}$ & $\begin{array}{c}\text { Optimum Cure Time } \\
\boldsymbol{t}_{\boldsymbol{c} \boldsymbol{0} \boldsymbol{0}}(\mathbf{m i n})\end{array}$ \\
\hline $50 / 50$ & 0.36 & 7.34 & 6.98 & 0.32 & 4.05 \\
$50 / 50 / 5$ & 0.33 & 7.03 & 6.70 & 0.40 & 3.10 \\
$50 / 50 / 10$ & 0.34 & 7.63 & 7.29 & 0.37 & 3.31 \\
$50 / 50 / 30$ & 0.35 & 8.34 & 7.99 & 0.34 & 4.25 \\
$50 / 50 / 50$ & 0.34 & 9.82 & 9.48 & 0.36 & 5.37 \\
\hline
\end{tabular}




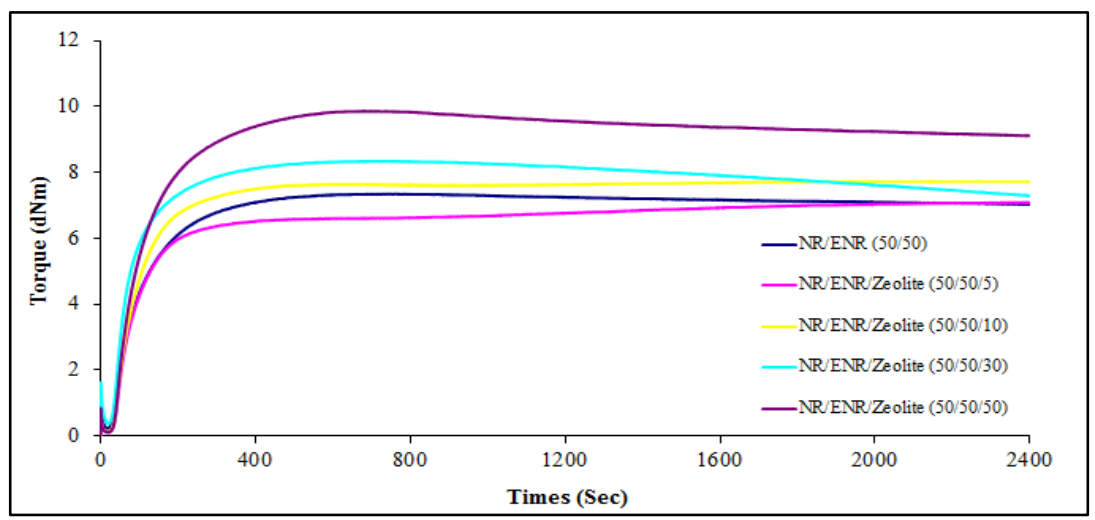

Figure 1. The curing characteristics of the NR/ENR/Zeolite compounds

\section{Mechanical properties}

Figure 2 presents the mechanical properties of the NR/ENR/Zeolite compounds. The change in tensile strength and elongation at break is related to the crosslinking density of the compounds, it was found that tensile strength improved with increasing zeolite loading up to $10 \mathrm{phr}(15.25 \mathrm{MPa})$. The zeolite containing at beyond $10 \mathrm{phr}$, the mechanical properties reduced, because of the inability of the filler to support the stresses [6] and there may have been poor dispersion or agglomerations of the filler in the rubber $[8,11]$. The elongation at break decreased with increasing zeolite content (from $950.36 \%$ at $5 \mathrm{phr}$ to 777.20 at $50 \mathrm{phr}$ ).
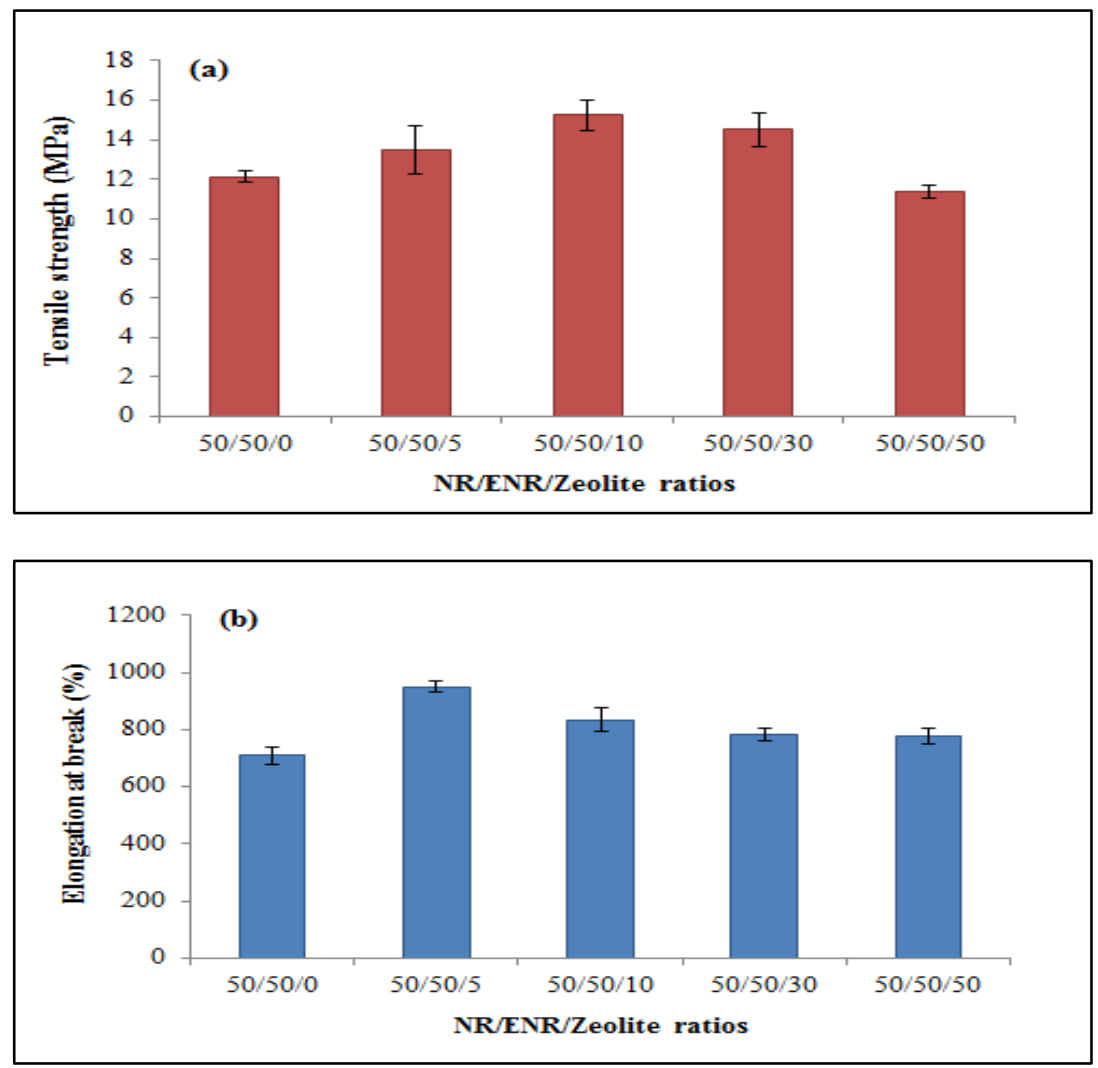

Figure 2. Effect of composition on the tensile strength (a) and elongation at break (b) for the NR/ENR/Zeolite 


\section{Swelling behavior}

Figure 3 shows the swelling of NR/ENR/Zeolite, the addition zeolite into the NR/ENR blends exhibited higher degrees of swelling than the loading of without zeolite filled NR/ENR blends. Addition of zeolite increased the swelling ratio with increasing content of zeolite due to good dispersion of zeolite and strong interactions between zeolite and rubber matrix. In addition, NR/ENR/Zeolite (50/50/50) swelling ratio decreased due to agglomerations of zeolite [10].

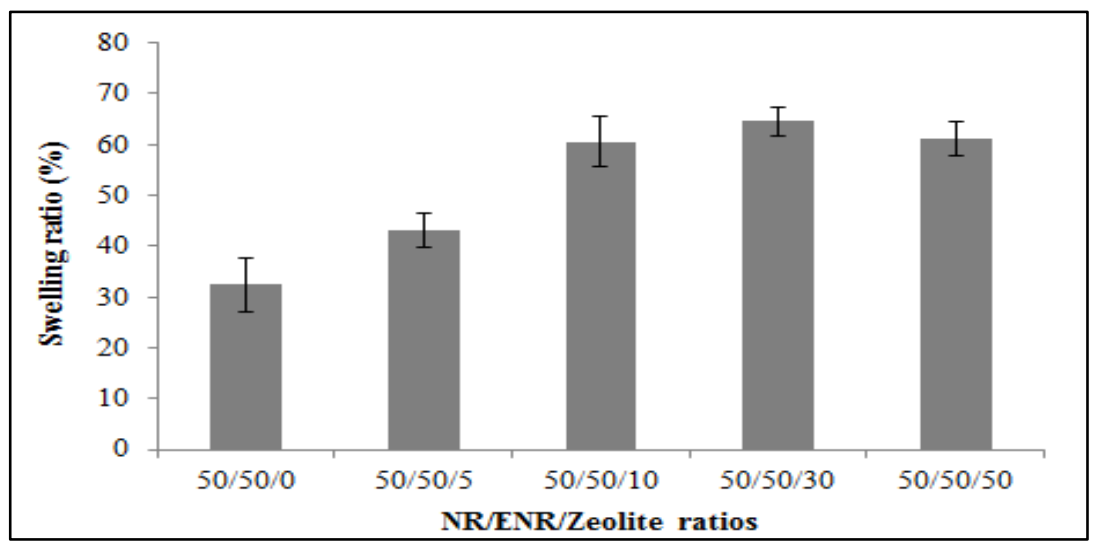

Figure 3. The swelling of the NR/ENR/Zeolite

\section{Membrane morphology}

Figure 4 presents the SEM micrographs of the surface of the membranes. The pores increased with the increasing of zeolite loading. The porosity results in the molecules are adsorbed on porous surfaces. It has the ability to permeable membrane well. The pore development is clearly seen and gave smooth surface in NR/ENR/Zeolite (50/50/30) [Figure 4(b)] and NR/ENR/Zeolite (50/50/50) [Figure 4(c)] membranes. Interestingly, zeolite is not just as reinforcing filler but also has potential as pore former on the membranes. The pore size was determined via visual investigation using scanning electron microscopy. It was found that the average pore size of the NR/ENR/Zeolite was in the range of $2-5 \mu \mathrm{m}$. However, the more pore developed can deduced the weak interaction between zeolite and NR/ENR which may affect the mechanical properties of the membrane because formation agglomerations of zeolite [3].
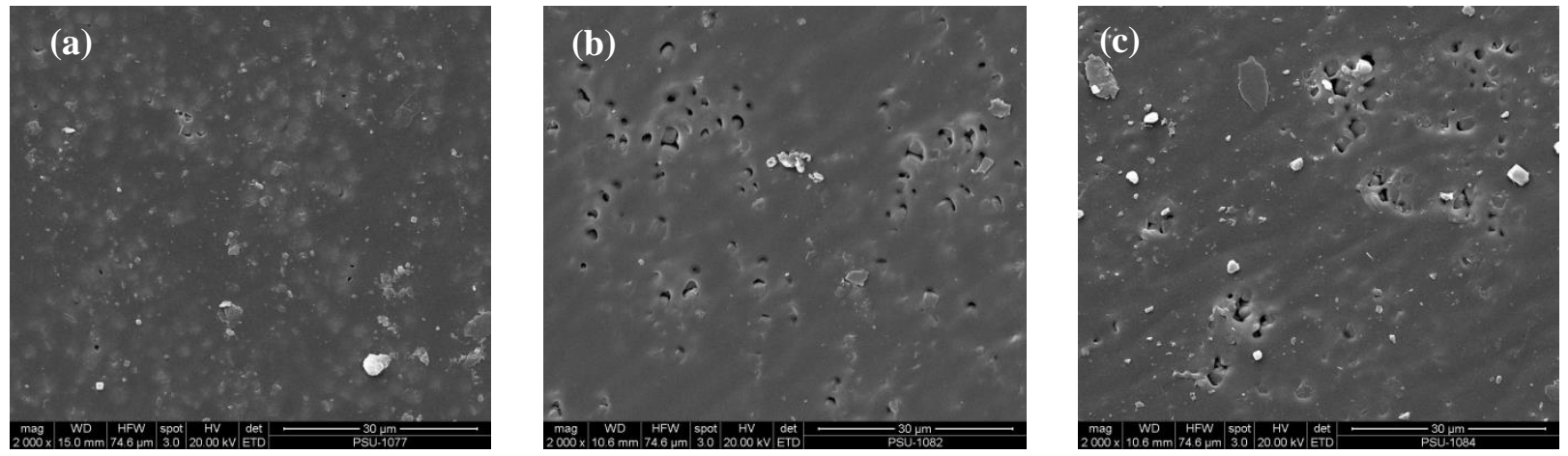

Figure 4. SEM micrographs of (a) NR/ENR/Zeolite (50/50/10), (b) NR/ENR/Zeolite (50/50/30) and (c) NR/ENR/Zeolite (50/50/50) 


\section{Phatcharasit \& Taweepreda: THE EFFECTS OF ZEOLITE ON MECHANICAL AND MORPHOLOGICAL PROPERTIES OF NR/ENR MEMBRANES}

\section{Conclusion}

The NR/ENR/Zeolite membranes were prepared by two-roll mill. As the amount of zeolite in the membrane increased, swelling property increased due to adsorption on the surface and the cure time $\left(\mathrm{tc}_{90}\right)$ increased due to incorporation of natural zeolite in the rubber matrix produced a better crosslink density. The mechanical properties of the membranes improved with the incorporation of zeolite with NR/ENR/Zeolite (50/50/10) membrane exhibited better mechanical properties as compared to NR/ENR/Zeolite (50/50/30) and NR/ENR/Zeolite (50/50/50) membranes has the lowest mechanical properties because agglomerations of zeolite. SEM micrographs were found that the pores increased with the increasing of zeolite loading.

\section{Acknowledgement}

The authors would like to thank Department of Rubber and Polymer Engineering, Faculty of Engineering, Thaksin University and Department of Materials Science and Technology, Faculty of Science, Prince of Songkla University.

\section{References}

1. Jon, N., Samad, N., Abdullah, N. A., Abdullah, I. and Othaman, R. (2013). Influence of silica addition on the properties of epoxidised natural rubber/polyvinyl chloride composite membrane. Journal of Applied Polymer Science, 129(5): 2789-2795.

2. Faita, F. L., Dotto, M. E. R., Franca, L. G., Cabrera, F. C., Job, A. E. and Bechtold, I. H. (2014). Characterization of natural rubber membranes using scaling laws analysis. European Polymer Journal, 50: 249254.

3. Samad, N. A., Othaman, R. and Abdullah, I. (2014). Preparation and characterization of epoxidised natural rubber/polyvinyl chloride/rice husk (ENR/PVC/RH) thin film composite by solution casting technique. International Journal Materials Engineering Innovation, 5(1): 61-69.

4. Chantara, T. R., Sabariah, K., Yaganaidu, S., Marina T. and Norzawani, Y. (2006). Radiation crosslinking of rubber phase in poly(vinyl chloride)/epoxidized natural rubber blend: Effect on mechanical properties. Polymer Testing, 25(4): 475-480.

5. Barbosa, G. P., Debone, H. S., Severino, P., Souto, E. B. and da Silva, C. F. (2016). Design and characterization of chitosan/zeolite composite films-effect of zeolite type and zeolite dose on the film properties. Materials Science and Engineering: C, 60: 246-254.

6. Siriyong, T. and Keawwattana, W. (2012). Utilization of different curing systems and natural zeolite as filler and absorbent for natural rubber/nitrile rubber blend. Kasetsart Journal (Natural Science), 46(6): 918-930.

7. López-Manchado, M. A., Arroyo, M., Herrero, B. and Biagiotti, J. (2003). Vulcanization kinetics of natural rubber-organoclay nanocomposites. Journal of Applied Polymer Science, 89(1): 1-15.

8. Cuong, M. V., Huong, T. V. and Hyoung, J. C. (2015). Fabrication of natural rubber/epoxidized natural rubber/nanosilica nanocomposites and their physical characteristics. Macromolecular Research, 23(3): 284290.

9. Hazwani, S. A., Hanafi, I. and Azura, A. R. (2016). Tensile Properties and Morphology of Epoxidized Natural Rubber/Recycled Acrylonitrile-Butadiene Rubber (ENR 50/NBRr) Blends. Procedia Chemistry, 19: 359 - 365.

10. Gopakumar, S. and Gopinathan Nair, M. R. (2005). Swelling characteristics of NR/PU block copolymers and the effect of NCO/OH ratio on swelling behavior. Polymer, 46: 10419-10430.

11. Soney, C. G., Manfred, K. and Sabu, T. (1999). Effect of nature and extent of crosslinking on swelling and mechanical behavior of styrene-butadiene rubber membranes. Journal of Membrane Science, 163: 1-17.

12. Ansarifar, M. A. and Nijhawan, R. (2000). Effects of silane on properties of silica filled natural rubber compounds. Journal of Rubber Research, 3(3): 169-184.

13. Tan, E. H., Wolff, S., Haddeman, M., Grewatta, H. P. and Wang, M. J. (1993). Filler-elastomer interactions. Part IX. Performance of silicas in polar elastomers. Rubber Chemistry and Technology, 66 (4): 594-604. 